\title{
Cuba's Latin American Medical School: Can Socially-Accountable Medical Education Make a Difference?
}

\section{Conner Gorry MA}

After graduating more than 12,000 doctors since its founding in 1999, Cuba's Latin American Medical School (ELAM, the Spanish acronym) is tackling one of its greatest challenges to date: how to track graduates from over 65 countries and measure their impact on health outcomes and policy in their local contexts?

ELAM, with its main campus at a former naval academy on the outskirts of Havana, extends scholarships to young people from around the world-most of whom otherwise would not have the means to become doctors. The ELAM curriculum is a six-year course of study designed to graduate physicians who will provide relevant, quality care while fostering equity and improving individual and population health outcomes.[1] ELAM's framework for recruiting, educating, and retaining students is intended to reinforce these goals by:

- Recruiting students from rural, remote, resource-scarce and other disadvantaged communities with the greatest health needs;

- Providing full, six-year scholarships to all students;

- Encouraging students to commit to practice as primary care physicians in underserved areas upon graduation;

- Integrating concepts of prevention, social determinants of health, and active community partnering into curriculum design;

- Using a community-based, service-learning methodology, preparing students to resolve local health problems; and

- Providing post-graduate clinical, research, and continuing education opportunities.

This strategy responds directly to what The Lancet characterizes as the failure of medical education "to overcome dysfunctional and inequitable health systems because of curricula rigidities, professional silos, static pedagogy, insufficient adaptation to local contexts, and commercialism in the professions. Breakdown is especially noteworthy within primary care, in both poor and rich countries."[2] Whereas the global debate once focused on the number and distribution of health workers, this shift towards the type of training signifies deeper consideration of the relationship between medical education, population health and health systems as a whole. Furthermore, it recognizes that new solutions are needed as the global health picture becomes more complex due to the international transfer of pathogens and people; continuing brain drain from the Global South to developed countries; emerging and re-emerging diseases; and widening health disparities. Complicating this scenario even further is inequitable access to care- primary care in particular-both within and among countries. In short, fresh thinking must be applied to health professionals' education if there is to be any hope of achieving health for all and global health security.

In this vein, ELAM and a handful of other medical schools worldwide have adopted the central mandate of social accountability, developing problem- and service-based learning, participatory action research, and other linkages between medical education, health systems development and population health equity. Char- acterized by curricula that transfer learning from the classroom to the community while emphasizing equity, they formed a consortium in 2008 to begin strengthening their evidence base, voice and influence.

This Training for Health Equity Network (THEnet) provides a framework for such socially-accountable medical schools to share tools, data, and experience in an effort to promote the innovations needed to confront the global crisis in human resources for health. The first step to begin evaluating impact across such diverse contexts and cultures-THEnet schools are found in Australia, Africa, Asia, Europe and the Americasis learning where, how and with whom graduates from these schools are working.

Social accountability in medical education is defined as an institutional responsibility to orient teaching, research, and service activities to address priority health needs with a particular focus on the medically underserved.

- THEnet's Social Accountability Evaluation Framework[3]

\section{Tracking ELAM Students and Grads}

Unlike the rest of the schools in THEnet, ELAM is both big and diverse. Indeed, it is the world's largest and most diverse medical school. Rector Juan Carrizo says such heterogeneity represents the institution's biggest challenge, dealing with "different customs and culture, language and habits." Yet, he says the school's strength also lies in diversity, as students live and work amongst peers from many different cultures, and lifelong relationships are built across borders.[4]

For once, if you're poor, female or from an indigenous population, you have a distinct advantage.

-Dr Margaret Chan, WHO Director-General, on a visit to the Latin American Medical School

Such size and diversity obliges ELAM administrators to systematically evaluate their own policies and outcomes-from student intake and curricular content, to job placement and career continuum-in order to remain effective and relevant to the school's mission. Through information technologies, and by adapting and contributing to a social accountability evaluation framework developed by THEnet in partnership with flagship schools, ELAM is striving to better gauge its impact by tracking its graduates' trajectories.

The cornerstone of this effort is an interactive, student and graduate project called the Observatory. Built by Cuban software developers using open access technology, the Observatory is a virtual infrastructure providing school administrators a detailed picture of where, how and with whom ELAM doctors work. Comprehensive and flexible, the database is supported by a dynamic analysis package through which variables are parsed to track graduates 


\section{Feature}

and assess their impact on health and health policies. "Right now we're training the people necessary to make the Observatory as effective as possible," Observatory director Dr Kenia Monjes explained, "since data reliability and analysis depend first and foremost on relevant, accurate data collection."

Students are entered into the Observatory database immediately upon matriculation to begin capturing relevant information and facilitate networking among ELAM stakeholders throughout their education in Cuba, upon graduation, and beyond. Dr Monjes stressed that tracking students from the beginning provides an important tool for decision-making. For example, assessing attrition and other difficulties offers a guide to improving processes for selecting scholarship candidates, while feedback from graduates helps hone the relevance of course content.

In addition to standard fields such as graduating class and contact information, variables include: whether doctors are unemployed or working in the public or private health sector; if they are involved in social service projects; if they practice or are enrolled in postgraduate studies in their country of origin, Cuba, or a third country; what specialty they are pursuing; and their availability for postings with Cuban disaster relief teams.

\section{The Observatory's Challenges}

"The infrastructure and technology are in place and we already have over 22,000 students and graduates from 95 countries entered into the database," Dr Monjes told MEDICC Review. "But we are still struggling to find where many of these graduates are working once they leave Cuba."

The chart below illustrates some first results for neighboring Haiti, where ELAM has become the main source of newly-trained physicians.

Employment Status of Haitian ELAM Graduates, $2012(n=748)$

\begin{tabular}{l|r|r|}
\hline Status & Number & $\begin{array}{c}\text { \% of } \\
\text { Graduates }\end{array}$ \\
\hline Working with Cuban health team in Haiti & 46 & 6.1 \\
\hline Working in Haiti's public health system & 193 & 25.8 \\
\hline Completing social service in Haiti's public & 114 & 15.2 \\
health system & 98 & 13.1 \\
\hline Working in private practice in Haiti & 451 & 60.3 \\
\hline Total working in Haiti & 110 & 14.7 \\
\hline Working outside Haiti & 187 & 25.0 \\
\hline Unemployed & 748 & 100.0 \\
\hline TOTAL & & \\
\hline
\end{tabular}

Source: Global Links, 2012

The Observatory's first litmus test came in January 2010, when ELAM administrators sent out the call for volunteers to join Cuba's Henry Reeve Team of Medical Specialists in Disasters and Epidemics in Haiti.[5] The earthquake, which struck the country on January 12, hit close to home: not only had more than 500 young Haitians doctors already graduated from ELAM, but the tremor was felt by students at the school's Santiago campus in eastern Cuba.[6] With student support, the Observatory went into action, contacting more than 2000 ELAM-trained doctors, half of whom affirmed they were available and eager to serve.[7] Over 700 of these doctors from 27 countries eventually joined the team in
Haiti, marking this the first time foreign medical graduates served alongside their Cuban colleagues in a disaster relief effort.

"The overwhelming response by graduates to volunteer in Haiti showed that these doctors were ready to put into practice the principles of social accountability that underpin their training," said Dr Monjes. The Haiti experience kick-started aggressive networking efforts by the Observatory, resulting in identification of an array of projects, organizations and experiences led by ELAMtrained doctors, some of which are described below. The Observatory, together with THEnet's evaluation framework, will allow such programs to be documented and assessed with appropriate methodology to determine their outcomes, replicability and social impact-going beyond anecdotal material to provide a sound evidence base.

\section{From Argentina to California: Fulfilling the Mission}

Two pillars of Cuban medical education, which ELAM students apply in service-learning rotations in the country's primary care system, are the neighborhood health diagnosis and the Continuous Assessment and Risk Evaluation (CARE; known as dispensarización in Spanish). Both tools are used to assess the health picture and needs of the local population to better tailor services and design strategies to improve outcomes. The first is a complete health diagnosis carried out annually by community-based health professionals; the second, conducted more often, classifies residents by chronic disease and risk factors.[8] In many of the contexts where ELAM graduates work, such needs assessments revealed a stark reality: health services were either non existent, insufficient, or inconsistent. In response, the ELAM doctors profiled below-what The Lancet refers to as "enlightened change agents"[2] — set out to put their problem-based, sociallyaccountable training to the test.

El Salvador: A member of ELAM's first graduating class in 2005, Dr Carlos Manuel Orantes received his MD upon completing six years of study and passing Cuba's national board exams. This degree proved a means rather than an end, however, since it allowed Dr Orantes to pursue his true passion: nephrology. Under the Cuban program, he won a scholarship to specialize at Havana's Nephrology Institute, where he developed primary research on renal disease in EI Salvador for his thesis.

As a result of his initial-and disturbing - findings that chronic kidney disease (CKD) was epidemic among younger people in the Salvadoran countryside, he returned to El Salvador in 2009 to launch more in-depth research. Named Nefrolempa, the study is being conducted in the total population of various communities of the Bajo Lempa region where he grew up. Adopting the methodology applied in a similar study on Cuba's Isle of Youth[9] - the first of its kind in the world-Nefrolempa set out to establish the prevalence of CKD, identify associated risk factors and measure kidney function in the population. Results thus far reveal that over $25 \%$ of men in the region suffer from different stages of CKD, much higher rates than the global prevalence of between $10 \%$ and $16 \%$, and among much younger people.[10] The alarm sounded.

Building on the basic tenets of a socially-accountable approach that research should be relevant, participatory, and equitable, the Nefrolempa team-comprised of 50 Salvadoran ELAM graduates and students, young students and doctors from the University of El Salvador, local leaders, and a pair of Cuban nephrologists 


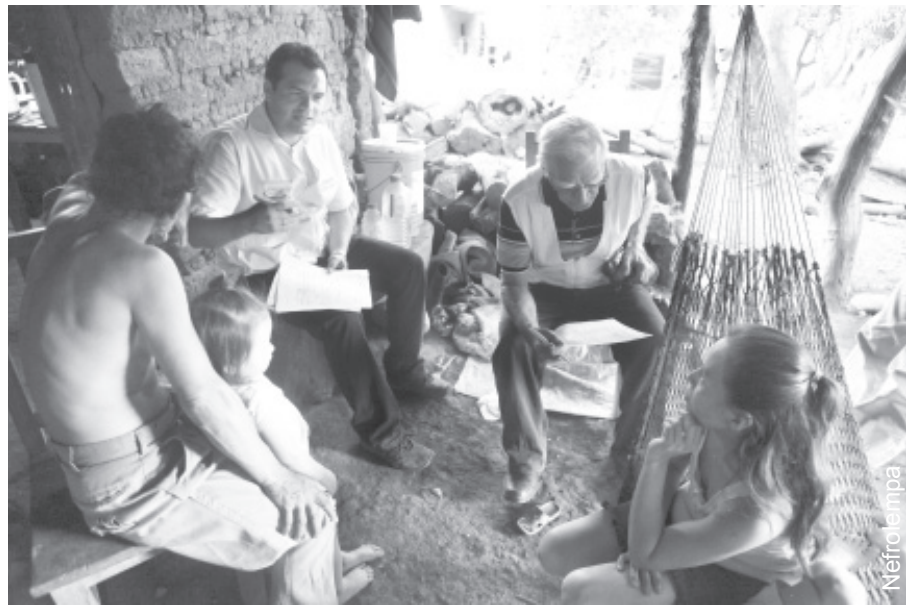

ELAM graduate and nephrologist Dr Carlos Orantes and PAHO advisor Dr Miguel Almaguer of Cuba at work in El Salvador's pioneering Nefrolempa study.

working under the aegis of $\mathrm{PAHO}[11]$ - extended the study to more communities, some of the poorest in the country.

The study's results spurred the Salvadoran Ministry of Health to develop a renal health program for the country's primary care system, complemented by a national renal research program. $\mathrm{Dr}$ Orantes designed the former and is national coordinator of the latter. "We designed and developed an integrated primary health program for early detection of CKD, and are in the process of reorganizing services at the community level to provide appropriate care," says Dr Orantes. "Implementation of these national services requires putting the necessary human resources in place, which is ongoing through service learning and training workshops."[11]

Nefrolempa, now in its second phase, bolstered by initial data from the national programs, led the Minister of Health, Dr María Isabel Rodríguez, to designate CKD a priority health problem. "Not only El Salvador, but the entirety of Central America is suffering from a chronic kidney disease epidemic that is debilitating our population, hammering our national budgets, and exhausting our health systems," declared Dr Rodríguez at the WHO/PAHO Non-Communicable Chronic Disease regional meeting in 2011.[12] At her urging, the meeting included the CKD epidemic in its final declaration.

In short, Nefrolempa, led by Dr Orantes, has alerted health authorities to CKD as a major health problem, led to national reorganization of services to address it, and sparked further research into risk factors for CKD as it manifests in El Salvador-particularly a potential association with toxic agrochemicals-all evidence of Salvadoran ELAM graduates affecting both policy and practice.

USA: Dr Brea Bondi-Boyd, ELAM class of 2009, is the first foreign medical graduate (FMG) to have been accepted into California's Contra Costa County Family Medical Residency program in decades. A native Californian, Dr Bondi-Boyd is one of nearly 200 young people from the United States who have earned scholarships to study medicine in Cuba[13]. Once she passed her US Medical Licensing Examinations ("The Boards"), she began the residency match process. "I was well received, but found, sadly, that my idealism, volunteerism and dedication to work with poor people that I largely learned from my Cuban professors, was not the norm for most US applicants, at least not in the applicant pool I came from."[14]

Dr Bondi-Boyd's experience goes to the heart of what distinguishes the training at a socially-accountable medical school from a traditional one. According to the Evaluation Framework for Socially Accountable Health Professional Education developed by THEnet, "schools help develop the values, norms, behaviors, and worldviews held by key groups in the health system. They can influence their graduates, with potentially wide-ranging effects throughout the health system."[3]

Dr Bondi-Boyd is applying those values in practice at the public hospital where she works, but also in policy, since she was chosen as a Youth Commissioner on the Education of Health Professionals for the $21^{\text {st }}$ Century Global Commission, an ongoing study published by The Lancet. Among the Commission's major findings, informed by the perspectives of Dr Bondi-Boyd and other young doctors from around the world, is that "20th century educational strategies are unfit to tackle 21st century challenges"[2]—something the ELAM and other socially accountable schools confront head on. "What's amazing about Cuban medical education is that it's based on public health, population assessment, and need: in short, it's already doing what much of the Commission recommends," said Dr Bondi-Boyd. As an ELAM graduate practicing in primary care, "I felt I could demonstrate to myself, and the US and international health communities, the possibilities of a universal health care system in low-resource settings."

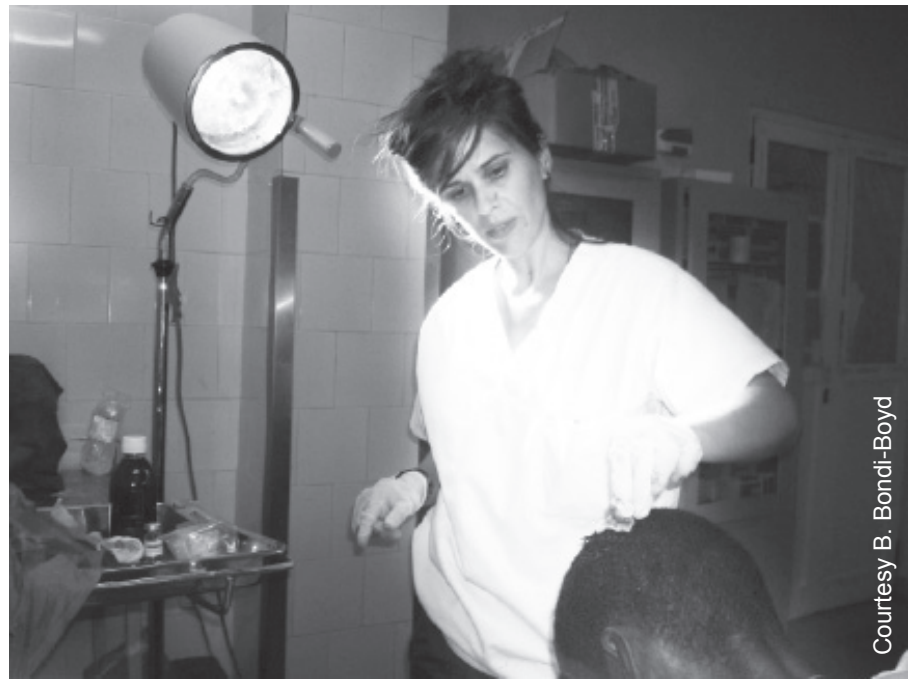

"ELAM's unique approach allows us to work among leader models, helping us to become change agents," says Dr Brea Bondi-Boyd, pictured here in a surgical rotation in Cuba.

Honduras: There was no electricity, school, or doctor where Dr Luther Castillo grew up in his indigenous community on the remote Honduran coast. As he walked to and from a school miles away, he was haunted by images of family and friends suffering from intestinal parasites, respiratory infections, low birthweight, and anemia. These conditions, though treatable, often resulted in worsening health and, too often, death due to lack of accessible care. He carried these images through six years of training at ELAM as he formulated a plan and organized other Honduran students to bring universal, equitable care home, to the Garifuna people of the Mosquito Coast. 


\section{Feature}
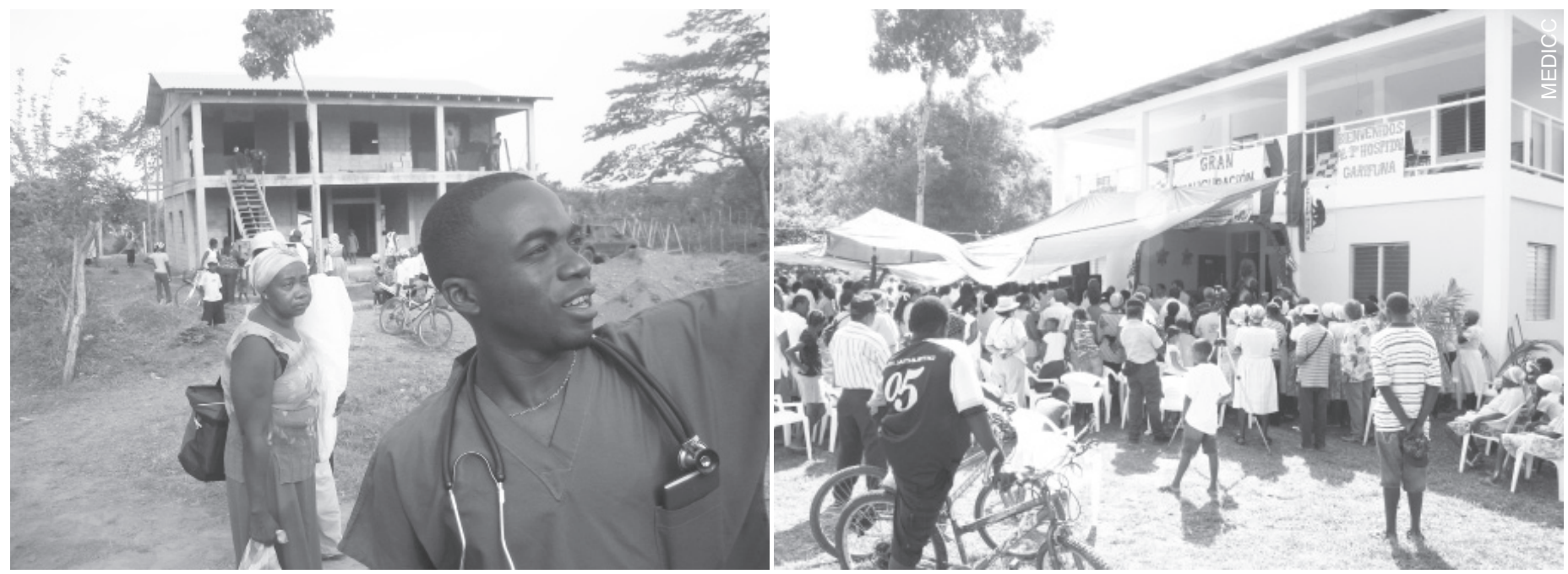

Dr Luther Castillo explains his vision for the First Garifuna Community Hospital, being built with local efforts and international support (I.); and the vision becomes reality in December 2007 with the hospital's official inauguration (r.).

In 2005, medical degree in hand, Dr Castillo returned home. The plan was ambitious: to organize the community itself to build a rural hospital staffed by other Garifuna ELAM-trained doctors in a strategic, accessible location; carry out health assessments of the surrounding population; and develop a comprehensive prevention and health promotion program. After long months of sweat equity, resources, and know-how donated by the community and international partners, the First Garifuna Community Hospital of Honduras opened in 2007 in the coastal town of Ciriboya. No small feat given the complex political and socio-economic conditions in Honduras then and now, this remote hospital amounts to a trial by fire for the principles of a socially-accountable medical education.

Five years on, the hospital is staffed 24 hours a day, seven days a week by a team of five Honduran ELAM-trained doctors who provide free emergency, internal medicine, surgery, laboratory, ultrasound, and primary care services to the surrounding population of 20,000. Another three ELAM graduates serve in a mobile capacity in the most remote communities and obstetric and dental services are provided by Cuban specialists posted to the area. $[15,16]$ Active screening and prevention campaigns for diabetes, hypertension, sexually-transmitted infections (including HIV), breast cancer and other conditions relevant to the local health picture are carried out by these health professionals.

In addition, ELAM graduates have developed training courses for midwives, nurses and health promoters. With local Garifuna leaders, they provide guidance to these communities and are active in health promotion, such as campaigns to increase breast feeding and prevent dengue. The hospital's efforts are supported by Student Health Teams, Garifuna ELAM students who dedicate their summers to working in communities back home. For the past two years, the Ciriboya-based team has conducted active screenings for breast cancer, sickle cell anemia and diabetes. By year's end 2011, the First Garifuna Community Hospital had treated over 231,000 people, attended 1630 births, performed nearly 2500 operations and saved 140 lives.[17]

Argentina: Like their colleagues in Honduras, ELAM graduates returned to Argentina to establish permanent, accessible health services to vulnerable, underserved communities. Propuesta Tatú, founded in 2008, is an intersectoral program with health, educational and cultural components offering primary care, pediatric, obstetric and mental health services free of charge in over a dozen communities on the outskirts of Buenos Aires. A MEDICC Review site visit to the 17 de Noviembre settlement where Propuesta Tatú is headquartered revealed the destitute conditions which prompted these ELAM-trained doctors to take action. Over 25,000 peoplemost of them indigenous immigrants from neighboring countrieslive in shanties amid open sewers and stagnant lagoons, bereft of basic utilities, the air heavy with burning plastic. "These settlements are typified by extreme poverty and have no municipal servicesno gas, water, schools, and no health services," Gino Straforini, Propuesta Tatú Coordinator and father of ELAM graduate Dr Carla Straforini, told MEDICC Review. "Our project was founded based on 'A Dignified Life for All,' beginning with medical attention provided by ELAM-trained doctors," he said.

From primary care services and prevention initiatives in a single settlement, Propuesta Tatú now serves 17 similar communities, staffed by 10 ELAM graduates and a handful of locally-trained

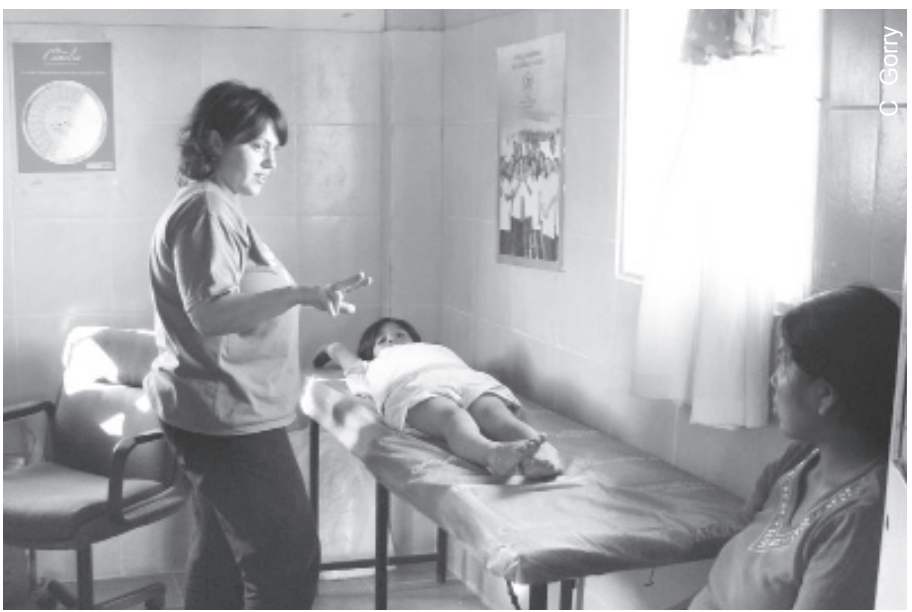

Physical rehabilitation is one of the services provided at Propuesta Tatú's Clinic in a settlement on the outskirts of Buenos Aires. 
doctors (including two orthopedists) and two psychologists. Through June 2012, these doctors had treated just shy of 30,000 people, provided over 1900 orthopedic consultations, and dispensed more than 26,000 prescriptions-all free of charge. Aggressive, ongoing efforts to address local health problems include dengue and Chagas disease detection, education and treatment; total population vaccination campaigns; and prevention of food- and water-borne diseases, including cholera and parasites.[18]

The scope of Propuesta Tatú has expanded since its founding to include efforts targeting the adverse effects of social determinants on health. Food and clothing distribution, nutrition and sexual health workshops, a literacy program using the Cuban method Yo Sí Puedo (winner of the UNESCO Literacy Award), housing construction, and a summer day camps for kids, all work towards the improvement of health and wellbeing in these communities. In addition, a school for health promoters and another for trades such as carpentry, computer sciences, and welding now impart classes to young people-several of whom have applied for ELAM scholarships as a result of their experiences.

Multiplying the impact of Propuesta Tatú and building sustainable, practical relationships with municipal authorities to further improve living conditions are priorities, Dr Straforini told MEDICC
When MEDICC Review sat down with Dr Dely amidst the rubble and tents of Port-au-Prince two months into his posting with Cuba's Henry Reeve disaster team, his dream to give back had solidified into a vision: "I want to see my country transformed, where Haitians feel proud, where children have access to health and education. Where I was born, there's no school. At age 10 or 11 , kids go work in the fields or emigrate. Sometimes it makes me cry to go back there. So I started thinking, what can I do?"[19] He not only started thinking, he started acting: two years on, Dr Dely's vision to establish an intersectoral community project based on education, health and social equity is a reality.

The École Bonne Samaritaine in his hometown of Madisse in north-central Haiti is the community's only school and embodies the comprehensive approach to health Dr Dely learned in Cuba. In addition to grade school classes for 182 local children, the École Bonne Samaritaine has a health clinic, staffed by Dr Dely, which provides basic primary care for students and their families plus a school meal and nutrition program-oftentimes offering the only meal these children receive each day.

This is just the beginning, according to Dr Dely, whose immediate goals are to establish a local hospital and to plant a community garden so students are guaranteed two nutritious meals a day.
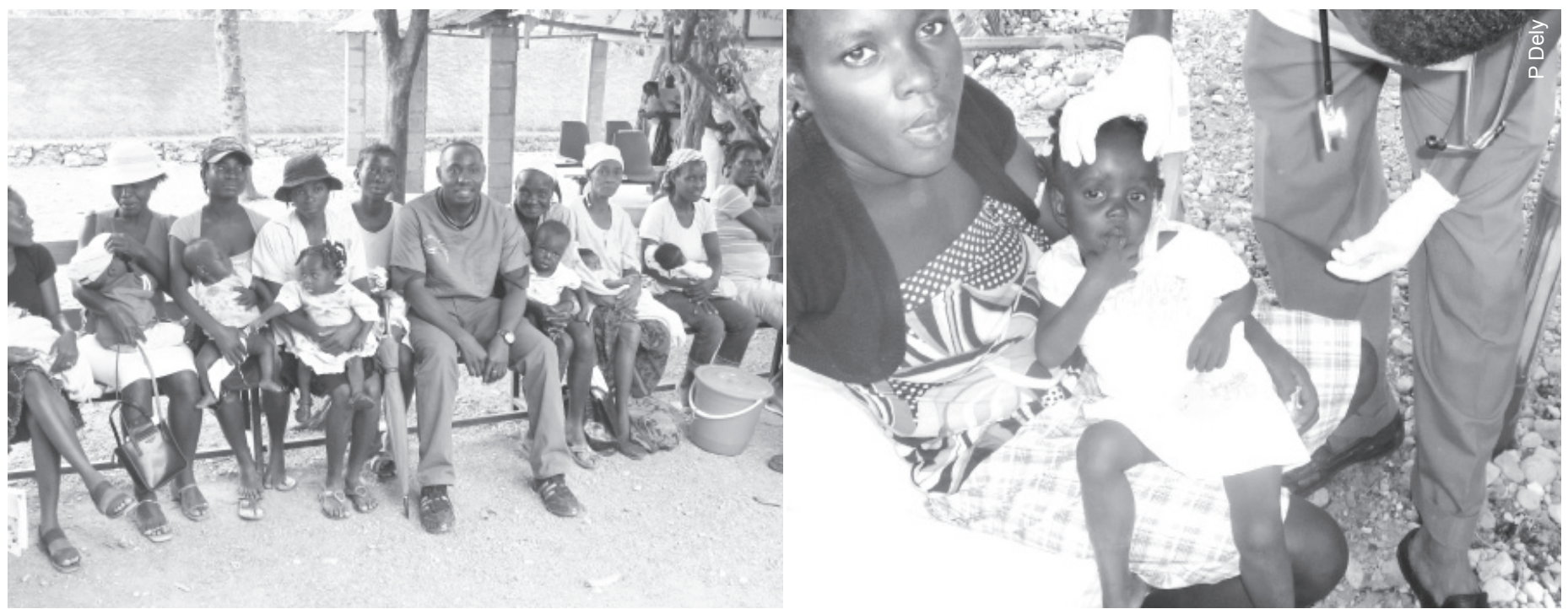

Dr Patrick Dely surrounded by students and their families outside the École Bonne Samaritaine, the school he founded in his home town (I.)... and where he also set up a cholera clinic to treat thousands of local residents (r.).

Review. "One municipality has contracted Propuesta Tatú doctors to work in a primary and urgent care center and we hope to extend Propuesta Tatú to Chile soon."

Haiti: Dr Patrick Dely didn't need to wait for the ELAM Observatory to find him following the earthquake that hit Haiti on January 12, 2010. He felt the ground moving in Santiago de Cuba where he was a resident in epidemiology, and immediately began organizing other Haitian ELAM graduates to join the relief effort. Dr Dely says that while his lifelong dream of becoming a doctor had been realized thanks to an ELAM scholarship, he knew it was time to go home and give back, even though it meant interrupting his postgraduate studies.
"My dream is for these kids to receive some of the best education in the country. I hope to see these children happy, healthy, and learning," he said.

While he works towards that goal, Dr Dely serves as Coordinator of the Haitian Ministry of Health's Epidemiology Department, a multipartite project supported by the US Centers for Disease Control; the option to obtain specialty degrees in an in-country training program led by Cuban specialists in Haiti allowed him to finally complete his studies.

This position has permitted him to put into practice epidemiological models learned in Cuba to confront the cholera epidemic in 


\section{Feature}

Haiti. "Once cholera was identified, we swung into action, converting the Bonne Samaritaine school into a rehydration and treatment center," Dr Dely told MEDICC Review. Previously, patients had to travel nearly an hour to the closest center, and too many simply never made it. "We treated more than 5000 people in the four months of the worst of the epidemic. The conditions were basic, but the service was free and accessible, allowing us to save many lives."[20]

\section{Forging Partnerships, Maximizing Impact}

One common denominator each of these experiences share is they all depend upon partnerships with stakeholders, local health professionals, health system administrators, policymakers and non-governmental organizations dedicated to providing health to underserved populations. Such well-directed multilateral cooperation in public health strategies-bringing additional financial, material, intellectual or technological resources-has proved to be an efficient, cost-effective strategy to address increasingly complex global health problems and their social determinants. This is especially true in areas lacking even basic infrastructure such as electricity, potable water, garbage disposal and transportation-often the precise areas where ELAM doctors commit to work.

In Haiti, Dr Dely's school clinic is supported by Global Links, a US organization dedicated to equipping health facilities in disadvantaged and underserved areas. Donations by Global Links of basic supplies including sutures, a blood pressure unit, nebulizers and a scale, enabled the clinic to open and begin attending and monitoring the health of the Madisse population.[21] Without similar donations from Global Links, MEDICC and other organizations[22], albeit on a much larger scale, the First Garifuna Community Hospital of Honduras would not exist. Other partners including the Fraternal Organization of People of Color, and a team of US volunteers that has supported the hospital since 2006, help keep the hospital running.

Data from the Observatory and experiences gleaned by ELAM graduates serving in poor communities reveal that regional and national governments have an integral and essential partnering role to play in maximizing impact of these public service doctors. After years of providing health and other services in settlements all but ignored by local government, Propuesta Tatú has finally been invited to partner with municipal health authorities in Buenos Aires. The Nefrolempa program in El Salvador is having considerable impact in this regard, as its participatory action research stimulated reforms in policy and practice at the national level, and influenced Central American regional priorities. The support of the Salvadoran Ministry of Health, PAHO and Cuban specialists, locally-trained doctors and the communities themselves helped make this possible.

Cooperation towards policy change is practical even in countries where medical associations and/or the government itself has been hostile to these returning doctors: in Honduras, the ELAM graduates at the First Garifuna Community Hospital weathered the 2009 military coup, regrouped, and proposed to the current government that primary care be legislated as national policy. This accord was recently made law: more than 1000 primary care health posts around the country currently without doctors, are slated to be staffed by physicians and nurses, many of them predicted to be ELAM graduates.[16]

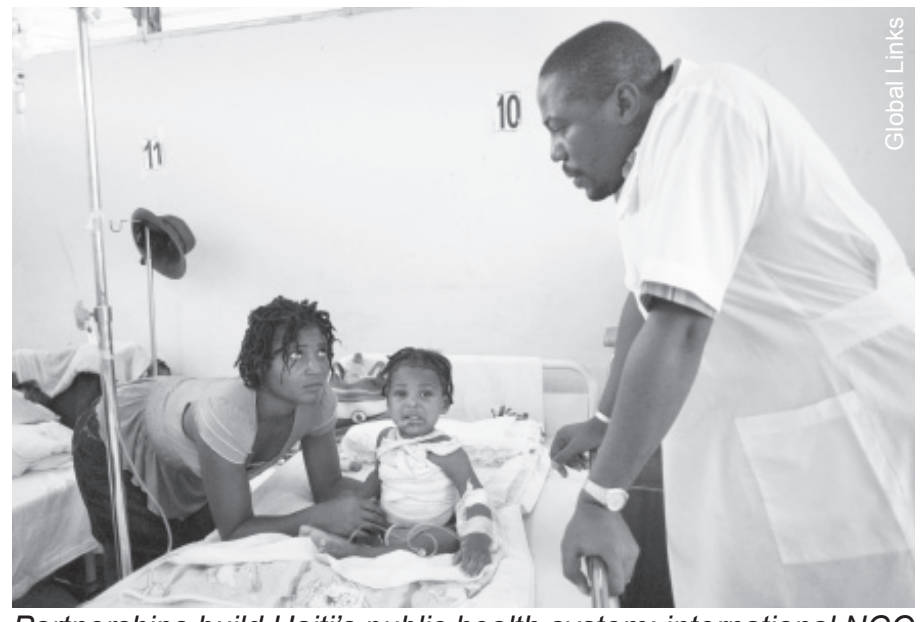

Partnerships build Haiti's public health system: international NGO donations put to work by Haitian ELAM graduates at the Hôpital Universitaire de la Paix.

Nowhere, however, is this multilateral synergy as robust as in Haiti, where regional governments-Venezuela, Brazil, and Cuba in particular, in partnership with organizations such as MEDICC and Global Links-are working together with Haitian authorities, PAHO, local NGOs and stakeholders to build quality, sustainable and accessible public health services, heavily staffed by ELAMtrained doctors.[23]

\section{Obstacles and Opportunities Ahead}

Nevertheless, one of the biggest hurdles remains recognition of the ELAM degree in many graduates' home countries. Unlike the United States, which essentially applies the same licensing requirements to both FMGs and domestic graduates, a number of countries in the Americas, Africa and Asia-perhaps accustomed more to 'brain drain' than 'brain gain'-have no mechanism for certifying these doctors and incorporating them into the health system. This is reflected in how many ELAM graduates remain unemployed, a factor the Observatory also tracks. "This is especially troubling [since] it represents the inability of some public health systems to absorb these new doctors," says ELAM Rector Juan Carrizo. Sometimes, he says, this failure is due to "budgetary constraints, but in other cases [it] represents resistance by local medical societies to accept graduates from a different kind of medical school."[24]

This is no small challenge, since measuring the impact of ELAMtrained doctors and therefore of the school itself, depends on how these physicians perform in the systems where they serve. According to $\mathrm{WHO}$, gauging progress toward socially accountable care is evaluated according to relevance, quality, cost-effectiveness and equity. Furthermore, "these values must be equally emphasized by the medical school and the health care system. Understanding the interrelationship between these values allows health planners and organizers to direct (or redirect) programmes of action."[25] These ELAM graduates are returning home with such values firmly established; but it is up to recipient countries to develop practical, sustainable and effective plans of action to incorporate them into their health systems to improve population health outcomes.

While it is beyond ELAM's purview to influence individual countries' domestic policies, mechanisms are being developed by the 
graduates-again with support and guidance from multilateral partners - to affect policy change. And the graduates themselves are organizing: SI-ELAM (Sociedad Internacional de Egresados de ELAM; International Society of ELAM Graduates) was constituted at the Second Meeting of ELAM Graduates held in Havana this July. SI-ELAM plans to work in cooperation with the Observatory to track policy shifts in countries with ELAM-trained doctors, as well as provide support to its members and postgraduate training in research to document and disseminate the impact of ELAM graduates' projects globally. SI-ELAM is an umbrella for national affiliates in dozens of countries, and Dr Emiliano Mariscal (ELAM class of 2005 and veteran of Propuesta Tatú in Argentina) was elected its first president.

As the world becomes ever more globalized, mobile and interdependent, solutions to problems faced by individual societies require innovative thinking and shared action. Nowhere is this more evident than in health, where preventable diseases, environmental disaster and contamination and inequities of all types (especially access to care) conspire to keep marginalized populations in a state of poor health. However, as the ELAM experience has shown, training doctors and other human resources for health is only half the battle; the other half is ensuring that those health professionals have the tools, networks, experiences, continuing education and opportunities to apply their training where it is most needed.

The ELAM Observatory is building the evidence base; beginning to measure the impact of its graduates; and informing other socially accountable medical schools and evaluation mechanisms with its unique perspective. These are the first steps to leveraging success and creating synergies with stakeholders and other partners. Already the experiences above have shown that ELAM-trained doctors can act as change agents in their communities, as well as role models for other low-income young people who dream of becoming doctors. For its part, with accurate and reliable data in hand, the Observatory will be able to tailor its research to inform continuous improvements in recruitment, curriculum, teaching methodologies and student retention. Although the impact of individuals on outcomes is difficult to measure given the multifactorial influences on health and well-being, working together, the ELAM Observatory, SI-ELAM and schools participating in TheNET are multiplying partnerships and spearheading socially accountable stewardship. By doing so, they hope to provide evidence that health for all is not only necessary but possible. $-1 /$ -

\section{References \& Notes}

1. For details of the ELAM curriculum, see: Cuban Medical Education: Aiming for the Six-Star Doctor, in MEDICC Rev. 2008;10(4):5-9.

2. Frenk J, Chen L, Bhutta ZA, Cohen J, Crisp N, Evans T, et al. Health professionals for a new century: transforming education to strengthen health systems in an interdependent world. Lancet. 2010 Dec 4;376(9756):1923-58.

3. The Training for Health Equity Network. THEnet's Social Accountability Evaluation Framework Version 1. Monograph I (1 ed.) [Internet]. Belgium: The Training for Health Equity Network; 2011 [cited 2012 Jun 20]. 28 p. Available from: http://thenetcommunity.org/files/articles/Monograph\%20print\%20quality\%20 feb\%201.pdf

4. Interview with Juan Carrizo. 2008 Jul 22.

5. For details on the founding of the Henry Reeve Team, see MEDICC Rev. 2005;7(8):31-2.

6. Martínez Hernández L. Amores de campamento. Granma. 2010 Feb 15.

7. Gorry C. Once the earth stood still (part I): Cuban rehabilitation services in Haiti. MEDICC Rev. 2010 Spring;12(2):44-7.

8. Keck CW, Reed GA. The curious case of Cuba [Internet]. AJPH. 2012 [cited 2012 Jun 20];102(8):e13-e22. Available from: http://ajph.aphapublications .org/doi/full/10.2105/AJPH.2012.300822

9. Almaguer M, Herrera R. Design and methodology of the Isle of Youth community-based epidemiological study of CKD, cardio-cerebral vascular disease, hypertension, and diabetes mellitus (ISYS). MEDICC Rev. 2007;9(1):23-30.

10. Orantes CM, Herrera R, Almaguer M, Brizuela EG, Hernández CE, Bayarre $\mathrm{H}$, et al. Chronic kidney disease and associated risk factors in the Bajo Lempa region of El Salvador: Neforlempa study, 2009. MEDICC Rev. 2011 Oct:13(4):14-22.

11. Interview with Carlos Manuel Orantes. 2012 Jul 13.

12. Rodríguez MI. Intervención, Consulta regional de alto nivel de las Américas contras las enfermedades crónicas no transmisibles. Mexico City. 2011 Feb 25. Spanish.

13. Porter C. Cuba-trained doctors making difference around the world [Internet] Toronto Star. 2012 Jun 2. Available from: http://www.thestar.com/news/world/ article/1203466--cuba-trained-doctors-making-difference-around-the-world

14. Interview with Brea Bondi-Boyd. 2012 Jul 2.

15. Dolmo C, Castillo Harry L. Brigada estudiantil por la salud: Luagu hatuadi waduheñu 2011 [unpublished monograph].

16. Interview with Luther Castillo Harry. 2012 Jul 17

17. Fundación Luagu Hatuadi Waduheñu. Datos históricos. Personal communication.

18. Interview with Gino Straforini. 2012 Jul 3.

19. Interview with Patrick Dely. 2010 Mar 18

20. Interview with Patrick Dely. 2012 Jul 17.

21. Global Links. Help Haiti heal newsletter. 2011 Dec 28.

22. MEDICC [Internet]. Oakland: Medical Education Cooperation with Cuba; c2012. Opening ceremonies for first indigenous Garifuna hospital in Honduras; 2007 Dec 1 [cited 2012 Jun 20];[about 1 screen]. Available from: http:// medicc. $\mathrm{org} / \mathrm{ns} / \mathrm{p}=264$

23. Field Notes from MEDICC [Internet]. United States: WordPress.com; c2012. Trilateral accord signed to rebuild Haitian public health system; 2010 Mar 30 [cited 2012 Jun 17];[about 2 screens]. Available from: http://mediccglobal .wordpress.com/2010/03/30/trilateral-accord-signed-to-rebuild-haitian-public -health-system/

24. Neusy AJ, Palsdottir B. Roundtable: Revisiting innovative leaders in medical education. MEDICC Rev. 2011;13(3):6-11.

25. Boelen C, Heck J. Defining and measuring the social accountability of medical schools. Geneva: World Health Organization; 1995. Report No.: WHO/ $\mathrm{HRH} / 95.7$.

Disclosures: MEDICC Review is published by Medical Education Cooperation with Cuba (MEDICC) mentioned in this article. 